\title{
Erratum to risk factors for postoperative sepsis-induced cardiomyopathy in patients undergoing general thoracic surgery: a single center experience
}

\author{
Editorial Office \\ Journal of Thoracic Disease \\ Correspondence to: Editorial Office. Journal of Thoracic Disease. Email: jtd@amepc.org.
}

doi: $10.21037 /$ jtd-2021-30

View this article at: https://dx.doi.org/10.21037/jtd-2021-30

Erratum to: J Thorac Dis 2021;13:2486-94

In the article that appeared on Page: 2486-2494, Vol 13, No 4 (April 2021) Issue of the Fournal of Thoracic Disease (FTD) (1), there was an omission of co-first authorship. Yinghua Wang and Xinming Zhai were both co-first authors. This article was corrected online.

Click here to view the updated version of the article.

Open Access Statement: This is an Open Access article distributed in accordance with the Creative Commons AttributionNonCommercial-NoDerivs 4.0 International License (CC BY-NC-ND 4.0), which permits the non-commercial replication and distribution of the article with the strict proviso that no changes or edits are made and the original work is properly cited (including links to both the formal publication through the relevant DOI and the license). See: https://creativecommons.org/ licenses/by-nc-nd/4.0/.

\section{References}

1. Wang Y, Zhai X, Zhu M, et al. Risk factors for postoperative sepsis-induced cardiomyopathy in patients undergoing general thoracic surgery: a single center experience. J Thorac Dis 2021;13:2486-94.

Cite this article as: Editorial Office. Erratum to risk factors for postoperative sepsis-induced cardiomyopathy in patients undergoing general thoracic surgery: a single center experience. J Thorac Dis 2021;13(7):4625. doi: 10.21037/jtd-2021-30 